\title{
Pengembangan Silabus Mata Pelajaran Desain Grafis Percetakan Berbasis Keterampilan Abad 21 pada SMK
}

\author{
Winda Nur Afifa, ${ }^{\circledR}$ Kherudin, Diana Ariani $^{2}$ \\ ${ }^{1}$ Universitas Negeri Jakarta, Jakarta, Indonesia. \\ ${ }^{2}$ Universitas Negeri Jakarta, Jakarta, Indonesia. \\ 3 Universitas Negeri Jakarta, Jakarta, Indonesia.
}

DOI: https://doi.org/10.210o9/JPI.031.o7

\begin{tabular}{l}
\hline Article History \\
\hline Received : 2020 \\
Accepted : 2020 \\
Published : 2020 \\
\hline Keywords \\
\hline Silabus, Successive \\
Approximation \\
Models 1 (SAM1), \\
Desain Grafis \\
Percetakan, \\
Keterampilan Abad \\
21, Sekolah \\
Menengah \\
Kejuruan. \\
\hline
\end{tabular}

\begin{abstract}
Abstrak
Penelitian ini mempunyai tujuan untuk menghasilkan sebuah silabus mata pelajaran Desain Grafis Percetakan berbasis keterampilan abad 21 pada sekolah menengah kejuruan. Penelitian pengembangan ini menggunakan model Successive Approximation Models 1 (SAM1) yang dipadukan dengan model desain silabus kurikulum 2013. Model Successive Approximation Models 1 (SAM1) terdiri dari 3 tahapan pengembangan yang diawali dan diakhiri dengan evaluasi, tahapan-tahapanya yaitu: (1) Evaluate (analisis), (2) Design, (3) Develop, (4) Evaluate. Penelitian ini menggunakan metode pengumpulan data melalui kuesioner untuk penilaian review ahli dan wawancara untuk uji coba satu-satu. Adapun hasil dari review ahli materi memperoleh skor 3.4 dan ahli desain pembelajaran memperoleh skor 3.8 untuk setiap komponen silabus dan skor $100 \%$ untuk prinsip pengembangan silabus. Berdasarkan hasil tersebut silabus yang telah dikembangkan memperoleh skor dengan kategori sangat baik. Sedangkan, hasil dari uji coba satu-satu diperoleh bahwa silabus yang dikembangkan sudah baik, dapat diterima, dan dapat dijadikan panduan oleh guru untuk mengembangkan RPP.
\end{abstract}

\begin{abstract}
This research aims to generate a syllabus for graphic design printing subject based on 21st-century skills in vocational high school. This development research uses Successive Approximation Models 1 (SAM1) integrated with the 2013 curriculum design model. Successive Approximation Model 1 (SAM1) consists of 3 development steps which begin and end with an evaluation, the steps are (1) Evaluate (analyze), (2) Design, (3) Develop, (4) Evaluate. This research uses questionnaires for expert evaluation and interviews for one-toone evaluation. The result of the subject-matter expert review is 3.4 and the instructional design expert is 3.8 for every component syllabus and $100 \%$ for principles of syllabus development. Based on predetermined criteria, the syllabus of the curriculum developed achieved a very good result. The result of the one-to-one evaluation indicates that the syllabus developed is good and accepted, and it could be used as a guide for the teacher to develop a syllabus.
\end{abstract}

Corresponding author : Winda Nur Afifa

(C) 2020 Universitas Negeri Jakarta

Adress: Universitas Negeri Jakarta

Jakata, Indonesia

E-mail: windanurafifa@gmail.com 


\section{PENDAHULUAN}

Era globalisasi dan pasar bebas yang terjadi membuat berbagai ketidakteraturan, yang membuat manusia dihadapkan pada perubahan-perubahan yang sangat kompleks dan tidak menentu. Hal tersebut telah menimbulkan jurang pemisah yang mengakibatkan hubungan yang tidak linear antara pendidikan dan dunia kerja atau "one to one relationship", karena apa yang terjadi dalam dunia kerja sulit diikuti oleh pendidikan sehingga terjadi kesenjangan. Dunia kerja saat ini dan ke depan akan fokus pada kompetensi sumber daya manusianya dibandingkan dengan kualifikasi pendidikan.

Apalagi saat ini dunia industri telah memasuki era baru yaitu era revolusi industri 4.0. Hal tersebut, ditandai dengan berkembangnya berbagai teknologi Artificial Intelligence (AI) atau kecerdasan buatan di masyarakat Teknologi artificial intelligence digunakan untuk meningkatkan efesiensi produksi dan peningkatan produktivitas serta daya saing. Namun, industri 4.0 tidak hanya membawa dampak positif tetapi juga tantangan baru untuk para tenaga kerja. Dimana, penggunaan teknologi artificial intelligence dalam industri akan memungkinkan terjadinya pergeseran tenaga manusia digantikan dengan robot yang akan menimbulkan pengurangan terhadap tenaga kerja. Menurut Kementerian ketenagakerjaan Republik Indonesia di era revolusi industri 4.0 akan ada pekerjaan yang hilang, dari beberapa penelitian yang dilakukan Oxford, McKinsey, Global Institute maupun Organisasi Buruh Indonesia (ILO) memprediksi akan ada 50\% jenis pekerjaan sekarang yang akan hilang. Namun akan ada $65 \%$ jenis pekerjaan baru yang belum dikenali sekarang.

Sebagai salah satu negara yang memiliki populasi terbesar di dunia. Saat ini, Indonesia memiliki jumlah penduduk usia produktif yang sangat besar. Dengan ini, Indonesia memiliki peluang untuk dapat meningkatkan pertumbuhan produktifitas masyarakatnya. Pada tahun 2018 penduduk Indonesia mencapai 265 juta jiwa dengan populasi kategori usia produktif (14-64 tahun)
179,13 juta jiwa atau sekitar $67,6 \%$ dari total populasi.

Supaya sumber daya tersebut dapat produktif dengan maksimal maka, perlu ditransformasikan menjadi sumber daya manusia yang mempunyai kompetensi dan keahlian dalam menghadapi perkembangan zaman. Pendidikan berperan penting dalam meningkatkan kualitas sumber daya manusia. Hal tersebut sesuai dengan fungsi pendidikan yaitu untuk mengembangkan kemampuan serta membentuk watak serta peradaban bangsa yang bermartabat dengan tujuan mencerdasakan kehidupan bangsa. Pendidikan sangat penting untuk menjamin peserta didik memiliki keterampilan belajar dan berinovasi, keterampilan teknologi dan media informasi, keterampilan bekerja, dan keterampilan bertahan dengan menggunakan keterampilan untuk hidup (life Skills). Upaya yang dapat dilakukan adalah memperbaiki kualitas pendidikan dengan menyesuaikan kurikulum sesuai perkembangan zaman serta meningkatkan kompetensi dan keahlian sumber daya manusia yang releven dengan tuntutan dunia kerja.

Uraian di atas sejalan dengan Instruksi Presiden Republik Indonesia Nomor 9 Tahun 2016 tentang revitalisasi Sekolah Menengah Kejuruan (SMK) dalam rangka peningkatan kualitas dan daya saing sumber daya manusia Indonesia. Sumber daya manusia Indonesia yang besar, perlu dipersiapkan secara matang agar terampil. Maka, strateginya adalah dengan menguatkan pendidikan kejuruan. Selama tahun 2016 sampai 2018 sekolah menengah kejuruan telah direvitalisasi untuk meningkatkan kompetensi lulusan, salah satu agenda revitalisasi yaitu dengan sinkronisasi dan penyelarasan kurikulum. Kurikulum sekolah menengah kejuruan dikembangkan sesuai dengan pertumbuhan pasar kerja dan beradaptasi dengan perkembangan ilmu pengetahuan dan teknologi, sehingga pendidikan jenjang ini merupakan pendidikan yang dinamis. Pendidikan sekolah menengah kejuruan akan selalu mengalami pergeseran orientasi mengikuti perkembangan teknologi dimasa yang akan datang. 
Abad 21 menuntut sumber daya manusia untuk memiliki keterampilan softskill maupun hardskill yang mumpuni agar dapat terjun ke dunia kerja dan siap berkompetisi dengan negara lain. Keterampilan yang harus dimiliki pada abad 21 menurut Trilling dan Fadel yang kemudia diperjelas oleh p21 (Partnership for 21st Century) adalah (1) Keterampilan hidup dan berkarir, ketrampilan ini ditujukan agar peserta didik dapat mengembangkan kecakapan hidup dan karir yang memadai untuk menentukan arah kehidupan yang kompleks dan lingkungan kerja di era persaingan informasi global. meliputi fleksibelitas dan adaptabilitas, inisiatif dan mengatur diri, interaksi sosial dan budaya, produktivitas dan akuntabilitas, kepemimpinan dan tanggung jawab. (2) Keterampilan belajar dan berinovasi, keterampilan ini untuk mempersiapkan peserta didik di masa depan. yang meliputi berpikir kritis dan menyelesaikan masalah, komunikasi, kolaborasi, kreativitas dan inovasi. (3) Keterampilan teknologi dan media informasi, keterampilan ini sangat penting karena pada abad 21 manusia hidup dalam lingkungan yang digerakan oleh teknologi dan media sehingga dituntut untuk kritis terhadap informasi, media dan teknologi. meliputi literasi informasi, literasi media, literasi ICT

Kurikulum sekolah menengah kejuruan menggunakan kurikulum 2013 yang telah disempurnakan. Pencapaian kompetensi pada kurikulum 2013 berdasarkan pada konsep kompetensi abad 21, pendekatan pembelajaran saintifik, dan penilaian autentik. Struktur kurikulum sekolah menengah kejuruan yang telah disempurnakan pada juni 2018 yaitu tentang spektrum keahlian sekolah menegah kejuruan, dimana terdapat perubahan jumlah bidang, program dan kompetensi keahlian yang disesuaikan dengan kebutuhan perkembangan zaman.

Pendidikan kejuruan mempersiapkan peserta didik untuk bekerja, oleh karena itu pendidikan yang digunkan adalah pendidikan berbasis kompetensi. Kurikulum berbasis industri didesain untuk mencapai tujuan pembelajaran sesuai dengan sisi kognitif, afektif dan psikomotorik peserta didik sekolah menengah kejuruan. Sehingga peserta didik diharapkan mampu mengadopsi keterampilan High Order Thingking skill atau HOTS, yaitu kemampuan untuk memecahkan masalah, kemampuan berfikir kritis, berfikir kreatif, kemampuan berargumen, dan kemampuan mengambil keputusan.

Berdasarkan hasil wawancara dengan guru program studi multimedia Sekolah Menengah Kejuruan Madani Brebes. Sekolah ini sudah menerapkan kurikulum 2013. Namun, dengan berlakukanya kurikulum 2013 revisi yang diterapkan pada tahun ajaran baru 2018 terdapat masalah dengan adanya mata pelajaran baru yaitu Desain Grafis Percetakan yang sebelumnya tidak ada pada kurikulum. Mata pelajaran desain grafis percetakan termasuk dalam mata pelajaran Kompetensi Keahlian (C3) yaitu kompetensi inti dan kompetensi dasar keahlian spesifik yang mewadahi kompetensi keahlian, berlaku khusus untuk kompetensi keahlian multimedia. Dari uraian di atas, dapat diketahui bahwa mata pelajaran ini sangat penting karena, mata pelajaran ini termasuk dalam keahlian spesifik yang harus dikuasai oleh peserta didik sebagai salah satu kompetensi lulusan program keahlian multimedia. Oleh karena itu, perencanaan pembelajaran sangat penting dilakukana agar pembelajaran dapat dilaksanakan secara efektif untuk mencapai kompetensi yang ditetapkan.

Dengan berlakunya mata pelajaran baru tersebut, guru mengalami kesulitan dalam menyesuaikan pembelajaran. Hal itu terjadi karena belum adanya silabus mata pelajaran Desain grafis percetakan. Sehingga, guru mengalami kesulitan dalam memilih materi apa saja yang akan dibelajarkan pada siswa, bagaimana kegiatan pembelajaran, bagaimana alokasi waktu pembelajaran dan sumber belajar yang akan digunakan.

Dari uraian permasalahan di atas, maka penelitian yang akan dilakukan adalah penelitian tentang pengembangan silabus pada mata pelajaran desain grafis percetakan yang di dalamnya mengandung kompetensi abad 21, yang berguna untuk membentuk kompetensi siswa program keahlian multimedia sekolah menengah kejuruan yang sesuai dengan 
kebutuhan di dunia usaha dan industri. Sehingga, lulusan sekolah menengah kejuruan dapat mengembangkan kompetensinya untuk bisa menghadapi tantangan revolusi industri 4.0 ini.

\section{METODE}

Pengembangan silabus ini dilakukan dengan menggunkan dua jenis model pengembangan yaitu Model Successive Approximation models 1 (SAM 1) Michael Allen yang dipadukan dengan model desain silabus pembelajaran Kurikulum 2013. Model Successive Approximation models 1 (SAM 1) digunakan dalam prosedur pengembangan secara keseluruhan, sedangkan model silabus pembelajaran kurikulum 2013 digunakan untuk desain pengembangan silabus itu sendiri. Tujuan atau hasil akhir pengembangan ini adalah menghasilkan produk pembelajaran berupa silabus pembelajaran.

Alat pengumpulan data yang digunakan yaitu kuesioner dan panduan wawancara. Dengan responden terdiri dari ahli materi, ahli desain pembelajaran, dan dua guru Multimedia. Teknik analisis data yang digunakan dalam penelitian ini adalah statistik deskriptif. Kuesioner untuk ahli media menggunakan penghitungan skala likert dengan skala instrument $4-1$. Sedangkan untuk ahli desain pembelajaran menggunakan dua skala yaitu skala instrumen Gutman Ya - Tidak untuk menilai prinsip pengembangan silabus dan skala likert dengan skala instrument $4-1$ untuk menilai setiap komponen silabus. Penilaian ahli desain pembelajaran menggunakan dua jenis instrumen dikarenakan pada instrumen untuk menilai prinsip pengembangan silabus terdapat indikator yang hanya bisa dijawab dengan tegas (Ya atau Tidak).

\section{Tabel 1 Kategori Nilai Skala Likert}

\begin{tabular}{ll}
\hline Rentang Nilai & Kategori Nilai \\
\hline $\mathbf{3 , 2 6}-\mathbf{4 , 0 0}$ & Sangat Baik \\
$\mathbf{2 , 5 1}-\mathbf{3 , 2 5}$ & Baik \\
$\mathbf{1 , 7 6}-\mathbf{2 , 5 0}$ & Kurang \\
$\mathbf{1 , 0 0}-\mathbf{1 , 7 5}$ & Sangat Kurang \\
\hline
\end{tabular}

Tabel 2 Kategori Nilai Skala Gutman

\begin{tabular}{ll}
\hline Rentang Nilai & Kategori Nilai \\
\hline $\mathbf{5 1 \%}-\mathbf{1 0 0 \%}$ & Baik \\
$\mathbf{0 \%}-\mathbf{5 0 \%}$ & Kurang \\
\hline
\end{tabular}

\section{HASIL DAN PEMBAHASAN}

Produk yang dihasilkan pada pengembangan ini adalah silabus mata pelajaran desain grafis percetakan berbasis keterampilan abad 21 pada Sekolah Menengah Kejuruan. Pengembangan silabus mata pelajaran desain grafis percetakan berbasis keterampilan abad 21 pada SMK Madani Brebes, menggunakan dua jenis model pengembangan yaitu Model Successive Approximation models 1 (SAM 1) Michael Allen yang dipadukan dengan model desain silabus pembelajaran Kurikulum 2013. Model Successive Approximation models 1 (SAM 1) digunakan dalam prosedur pengembangan secara keseluruhan, sedangkan model silabus pembelajaran kurikulum 2013 digunakan untuk desain pengembangan silabus itu sendiri. Langkah-langkah pengembangan yaitu sebagai berikut:

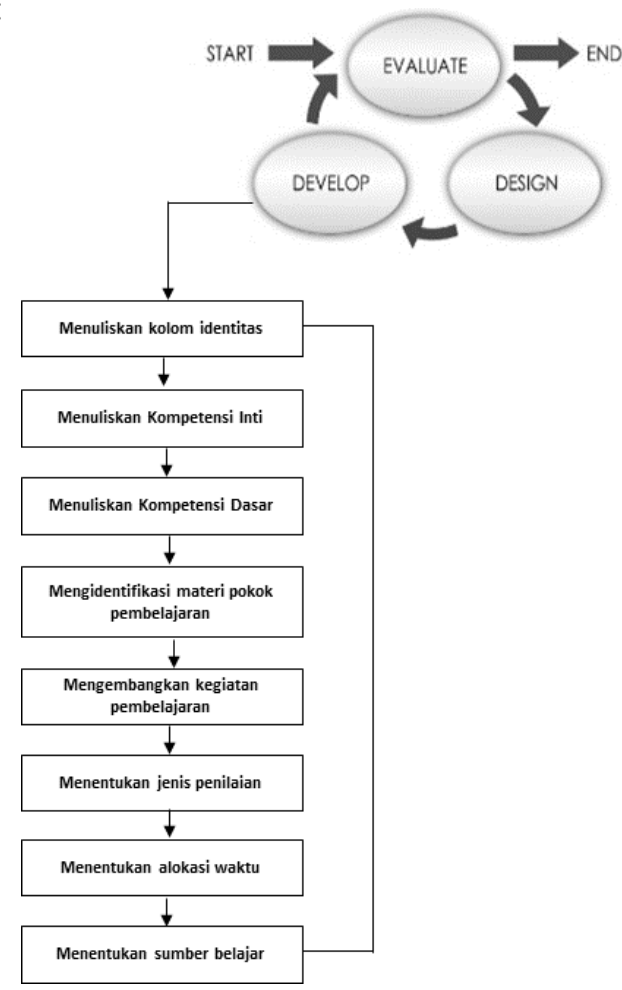


Gambar 1 Perpaduan Model Successive Approximation models 1 (SAM1) dan model silabus pembelajaran Kurikulum 2013

\section{Evaluasi (analisis)}

\section{a. Analisis Kebutuhan}

Tahap awal dilakukan dengan mengumpulkan informasi awal yang dilakukan dengan cara mewawancarai guru Multimedia dan tiga orang siswa SMK Madani Brebes. Berikut ini adalah hasil pengumpulan informasi pada tahap awal:

\section{Tabel 3 Analisis Masalah}

\begin{tabular}{lll}
\hline Kekurangan & Kebutuhan & Ideal \\
\hline 1. Tidak adanya & 1. Silabus mata & 1. \\
silabus pada \\
pelajaran & berbasis \\
mata & Desain & keterampilan \\
pelajaran & Grafis & abad 21 \\
Desain Grafis & Percetakan & \\
Percetakan & yang & \\
2. Perubahan & berpusat & \\
kompetensi & kepada & \\
dasar yang & peserta didik & \\
disesuaikan & dan sesuai & \\
dengan sesuai & dengan & \\
dengan & kebutuhan & \\
kebutuhan & dunia & \\
dunia & industry/ & \\
industry/ & dunia usaha & \\
dunia usaha & & \\
3. Materi & & \\
pembelajaran & & \\
yang masih & & \\
kurang & \\
mendalam & \\
4. Kegiatan & \\
pembelajaran & \\
yang belum & \\
berpusa pada & \\
peserta didik & \\
5. Bahan ajar & \\
yang kurang & \\
memadai & & \\
\hline
\end{tabular}

\section{b. Analisis Peserta Didik}

Peserta didik kelas 11 SMK termasuk dalam masa remaja, dimana pada masa ini peserta didik dapat berfikir secara logis, abstrak dan mempunyai penalaran yang konkrit. Untuk mengembangkan keaktifan peserta didik, kegiatan pembelajaran harus berpusat kepada peserta didik dan menggunkan metode pembelajaran yang variatif sesuai dengan kebutuhan peserta didik. Sedangkan, untuk menunjang gaya belajar peserta didik dapat memanfaatkan beragam sumber belajar baik audio maupun visual dan melakukan praktik langsung yang sesuai agar dapat membatu proses pembelajaran.

\section{Desain}

Pada tahap desain dilakukan perancangan proses pengembangan yaitu membuat rancangan desain kasar silabus dengan menggunakan model desain silabus kurikulum 2013 yaitu meliputi menganalisis kompetensi inti dan kompetensi dasar, dilanjutkan dengan menetapkan materi pokok pembelajaran, menentukan kegiatan pembelajaran dan penilaian, menetapkan alokasi waktu dan memilih sumber belajar. Pada tahap ini juga membuat kisi-kisi serta instrumen penelitian yang akan digunakan dalam evaluasi oleh ahli desain pembelajaran, ahli materi dan uji coba one to one.

\section{Pengembangan}

Pada tahap pengembangan, semua materi desain grafis percetakan dan juga prosedur pengembangan yang akan ditempuh dirancang kedalam bentuk silabus dengan data yang didapat dari tahap desain. Pengembangan silabus mengadopsi model desain silabus pembelajaran kurikulum 2013 dikarenakan kurikulum yang digunakan dalam pembelajaran di SMK Madani Brebes adalah kurikulum 2013. Tahapan-tahapan pengembangan silabus yaitu sebagai berikut:

\section{a. Menuliskan kolom identitas}

Pada tahap ini menuliskan kolom identitas diisi sesuai dengan nama sekolah, nama mata pelajaran, nama kelas, durasi (waktu) pelajaran.

b. Menuliskan kompetensi inti

Pada tahap ini menuliskan kompetensi inti sesuai dengan kompetensi inti yang akan dicapai dalam mata pelajaran desain grafis. 
Kompetensi inti dapat dilihat pada tahap desain.

c. Menuliskan kompetensi dasar

Pada tahap ini menuliskan kompetensi dasar sesuai dengan kompetensi dasar yang akan dicapai dalam mata pelajaran desain grafis percetakan yang diperoleh dalam tahap desain.

d. Mengidentifikasi materi pokok pembelajaran.

Pada tahap ini mengidentifikasi materi pokok pembelajaran berdasarkan hasil studi dokumen terhadap kompetensi inti dan kompetensi dasar. Materi pokok pembelajaran di atas kemudian dijabarkan lebih rinci lagi sesuai dengan tingkatan aktifitas/ranah pembelajaranya.

\section{e. Mengembangkan kegiatan} pembelajaran.

Pada tahap ini mengembangkan kegiatan pembelajaran yang dirancang dengan menyebutkan langkah-langkah utama pembelajaran yang akan dilakukan untuk mencapai suatu kompetensi dasar bagi peserta didik. Dalam memilih pengalaman belajar semua faktor yang diperlukan dalam kegiatan pembelajaran harus diintegrasikan dengan pendekatan keterampilan abad 21 yaitu berfikir kritis dan pemecahan masalah, kolaborasi, komunikasi, kreatifitas dan inovasi. Hasil pemilihan pengalaman belajar dilakukan dengan berdiskusi dengan guru, dan desainer pembelajaran hasil berupa kegiatan pembelajaran yang dapat dilihat pada silabus.

\section{f. Menentukan jenis penilaian}

Pada tahap ini menentukan penilaian hasil belajar yang akan digunakan. Penilain yang akan digunakan dipilih berdasarkan kompetensi dasar akan dicapai. Jenis penilaian yang digunakan dalam silabus yaitu penilaian otentik, penilaian unjuk kerja, dan fortofolio.

g. Menentukan alokasi waktu

Pada tahap mentukan alokasi waktu harus mempertimbangkan jumlah kompetensi dasar, keluasan, kedalaman, tingkat kesulitan dan tingkat kepentingan kompetensi dasar yang akan dicapai. Pembagian alokasi waktu didasarkan pada minggu efektif dan alokasi waktu mata pelajaran perminggu. Pada mata pelajaran desain grafis percetakan jumlah jam pelajaran dalam kurikulum 432JP. Sedangkan pembelajaran desain grafis percetakan di SMK Madani Brebes berlangsung 2 kali pertemuan seminggu selama 6 jam pelajaran (satu jam pelajaran $=45$ menit). Oleh karena itu, setiap kompetensi dasar yang akan dicapai mempunyai alokasi waktu pembelajaran yang berbeda sesuai dengan kebutuhan. (terlampir)

h. Menentukan sumber belajar.

Pada tahap ini menentukan sumber belajar yang akan digunakan untuk mempelajari materi tertentu sesuai dengan kompetensi dasar. sumber belajar yang digunakan dalam silabus ini seperti buku, PPT, Sotware desain grafis.

\section{Evaluasi}

a. Review Ahli

Setelah silabus mata pelajaran desain grafis percetakan dikembangkan sesuai dengan tahap-tahapan yang terdapat pada model SAM1 dipadukan dengan model pengembangan silabus kurikulum 2013, kemudian produk tersebut direview oleh para ahli dan diuji coba oleh pengguna. Review ahli dilakukan kepada 2 ahli yaitu ahli materi dan ahli desain pembelajaran. Tahap selanjutnya, pengembang melakukan uji 
coba silabus mata pelajaran Desain Grafis Percetakan secara satu-satu (one to one) kepada pengguna yaitu 2 orang guru program keahlian multimedia melalui wawancara.

\section{Tabel 4 Skor Review Ahli Materi}

\begin{tabular}{lll}
\hline No & Indikator & Rata-rata \\
\hline 1 & Relevansi & 3,7 \\
2 & Konsistensi & 3,5 \\
3 & Kecukupan & 3,25 \\
4 & Kebermanfaatan & 3 \\
Jumlah & $\mathbf{4 1}$ \\
Rata-rata keseluruhan & $\mathbf{3 , 4}$ \\
\hline
\end{tabular}

Berdasarkan hasil review yang dilakukan kepada ahli materi diperoleh nilai rata-rata sebesar 3,4. Hasil review ahli tersebut menunjukan bahwa kualitas produk dari segi materi dapat dikatakan sangat baik.

\section{Tabel 5 Skor Kelengkapan Prinsip Pengembangan Silabus}

\begin{tabular}{ll}
\hline Indikator & Skor \\
\hline Ya & 23 \\
Tidak & 0 \\
f & 23 \\
$\%$ & $100 \%$ \\
\hline
\end{tabular}

Hasil review yang dilakukan kepada ahli desain pembelajaran diperoleh skor 23 dengan prosentase $100 \%$. Hasil review tersebut menunjukan bahwa kualitas produk dari segi prinsip pengembangan silabus dapat dikatakan baik.

Tabel 6 Skor Ahli Desain Pembelajaran untuk komponen silabus

\begin{tabular}{lll}
\hline No. & Indikator & Rata-rata \\
\hline 1 & Identitas silabus & 4 \\
2 & Kompetensi Inti & 4 \\
3 & Kompetensi Dasar & 4 \\
4 & Materi Pembelajaran & 4 \\
5 & Kegiatan Pembelajaran & 4 \\
6 & Penilaian & 3,5 \\
7 & Alokasi waktu & 4 \\
8 & Sumber belajar & 2,6 \\
Jumlah & $\mathbf{1 1 0}$ \\
Rata-rata keseluruhan & $\mathbf{3 , 8}$ \\
\hline
\end{tabular}

Berdasarkan hasil review yang dilakukan kepada ahli desain pembelajaran diperoleh nilai rata-rata sebesar 3,8 untuk komponen dalam silabus. Hasil review ahli tersebut menunjukan bahwa kualitas produk dari segi komponen silabus dapat dikatakan sangat baik.

Berdasarkan data-data di atas, rata-rata review para ahli secara keseluruhan terhadap silabus mata pelajaran Desain Grafis Percetakan berbasis keterampilan abad 21 pada Sekolah Menengah Kejuruan yaitu sebagai berikut:

Tabel 7 Nilai Rata-rata Review Ahli

\begin{tabular}{lll}
\hline No. & Indikator & $\begin{array}{l}\text { Rata- } \\
\text { rata }\end{array}$ \\
\hline $\mathbf{1} \quad$ Ahli Materi & 3,4 \\
$\mathbf{2}$ & Ahli desain pembelajaran & 3,8 \\
Jumlah & 7,2 \\
Rata-rata keseluruhan & 3,6 \\
\hline
\end{tabular}

Dari hasil penghitungan rata-rata kualitas review ahli di atas diperoleh nilai 3,6. Hasil tersebut dapat dikatakan bahwa silabus yang dikembangkan mempunyai kualitas yang sangat baik pada setiap komponen silabus dan materi pembelajaran.

Tabel 8 Kelengkapan $\quad$ Prinsip Pengembangan Silabus

\begin{tabular}{lll}
\hline $\begin{array}{l}\text { Alternatif } \\
\text { Jawaban }\end{array}$ & $\mathbf{f}$ & $\mathbf{\%}$ \\
\hline Ya & 23 & 100 \\
Tidak & 0 & 0 \\
Jumlah & $\mathbf{2 3}$ & $\mathbf{1 0 0}$ \\
\hline
\end{tabular}

Dari hasil penghitungan kelengkapan prinsip pengembangan silabus di atas diperoleh skor untuk jawaban $\mathrm{Ya}=23$ dengan prosentase $100 \%$ dan Tidak $=0$ dengan prosentase $0 \%$ dengan jumlah nilai $100 \%$. Hasil review tersebut menunjukan bahwa kualitas produk dari segi prinsip pengembangan silabus dapat dikatakan baik. 
b. Evaluasi Satu-Satu (one to one)

Berdasarkan hasil uji coba satu-satu yang dilakukan kepada 2 orang guru multimedia diperoleh bahwa silabus yang dikembangkan sudah baik, dapat diterima, dan dapat dijadikan pandua oleh guru untuk mengembangkan RPP. Hal tersebut dapat dilihat dari hasil wawancara yang telah dilakukan diperoleh informasi bahwa setiap komponen yang dikembangkan dalam silabus yaitu (1) identitas sudah sesuai dengan identitas sekolah, (2) kompetensi inti dan kompetensi dasar sudah sesuai dengan kurikulum yang digunakan, (3) materi pembelajaran sudah sesuai dengan kompetensi dasar dan peserta didik, lengkap, dan detail, (4) kegiatan pembelajaran dan penilaian mempunyai alur yang jelas dan mendukung pengembangan keterampilan abad 21, (5) alokasi waktu dan sumber belajar sudah sesuai. Silabus juga dikembangkan secara rinci dan didukung dengan bahasa yang jelas dan mudah dipahami.

\section{SIMPULAN}

Tujuan penelitian pengembangan ini adalah menghasilkan Silabus Mata Pelajaran Desain Grafis Percetakan Berbasis Keterampilan Abad 21 pada SMK Madani Brebes. Pengembangan silabus ini menggunkan Model Successive Approximation models 1 (SAM 1) Michael Allen yang dipadukan dengan model desain silabus pembelajaran Kurikulum 2013. Model pengembangan Model Successive Approximation models 1 (SAM 1) terdiri dari terdiri dari 3 tahapan yaitu evaluasi, desain, dan pengembangan yang prosesnya dimulai dan diakhiri dengan evaluasi, penjabaranya sebagai berikut:

\section{Evaluasi (analisis)}

Pada tahap ini, pengembang melakukan wawancara dengan guru multimedia dan siswa multimedia kelas 11. Dari hasil wawancara pengembang mendapati masalah pada proses pembelajaran desain grafis percetakan bahwa pada pelajaran tersebut belum mempunyai silabus pembelajaran. Hal itu terjadi karena, mata pelajaran desain grafis percetakan adalah mata pelajaran baru pada kurikulum 2013 revisi 2018 yang disesuaikan dengan kebutuhan dunia industri/dunia usaha. Dari masalah yang ada, pengembang menemukan sebuah solusi terhadap masalah yang dihadapi yaitu mengembangkan silabus mata pelajaran desain grafis percetakan berbasis keterampilan abad 21 pada Sekolah Menengah Kejuruan.

\section{Desain}

Pada tahap ini, pengembang membuat rancangan desain kasar silabus dengan berpatokan pada desain silabus kurikulum 2013 yaitu meliputi menganalisis kompetensi inti dan kompetensi dasar yang kemudian dibuatkan peta kompetensi, dilanjutkan dengan menetapkan materi pokok pembelajaran, menentukan kegiatan pembelajaran dan penilaian yang terintegrasi dengan keterampilan abad 21, menetapkan alokasi waktu dan memilih sumber belajar.

\section{Pengembangan}

Pada tahap ini, pengembang mengembangkan silabus dengan data yang diperoleh dari tahap desain. Pengembangan silabus mengadopsi model desain silabus pembelajaran kurikulum 2013, tahapan pengembangan adalah sebagai berikut: menuliskan kompetensi inti, menuliskan kompetensi dasar, mengidentifikasi materi pokok pembelajaran, mengembangkan kegiatan pembelajaran, menentukan jenis penilaian, menentukan alokasi waktu, dan menentukan sumber belajar. 4. Evaluasi Pada tahap ini pengembang melakukan evaluasi produk melalui 2 tahap, yaitu:

\section{a) Review ahli}

Pada tahap ini, produk direview oleh ahli materi dan ahli desain pembelajaran memperoleh hasil ratarata 3,6. Untuk setiap komponen silabus dan materi pembelajaran. Dan pada penghitungan skor kelengkapan prinsip pengembangan silabus diperoleh prosentasi 100\%. Hasil tersebut dapat 
dikatakan bahwa silabus yang dikembangkan mempunyai prinsip pengembangan silabus yang baik.

b) Uji coba Satu-Satu (one to one)

Pada tahap ini, uji coba dilakukan kepada 2 orang guru multimedia dengan melakukan wawancara terstruktur. Hasil dari wawancara yang telah dilakukan diperoleh informasi bahwa setiap komponen yang dikembangkan dalam silabus yaitu (1) identitas sudah sesuai dengan identitas sekolah, (2) kompetensi inti dan kompetensi dasar sudah sesuai dengan kurikulum yang digunakan, (3) materi pembelajaran sudah sesuai dengan kompetensi dasar dan peserta didik, lengkap, dan detail, (4) kegiatan pembelajaran dan penilaian mempunyai alur yang jelas dan mendukung pengembangan keterampilan abad 21, (5) alokasi waktu dan sumber belajar sudah sesuai. Silabus juga dikembangkan secara rinci dan didukung dengan bahasa yang jelas dan mudah dipahami.

Silabus mata pelajaran Desain Grafis Percetakan berbasis keterampilan abad 21 yang dikembangkan memiliki kualitas yang baik. Walaupun demikian, masih terdapat kekurangan pada silabus tersebut. Kekurangan tersebutlah yang harus diminimalisir agar pengembangan silabus dapat lebih baik dari sebelumnya. Oleh karena itu, pengembang berupaya memberikan beberapa saran yang dapat menjadikan masukan yang bermanfaat. Berikut adalah saran dari pengembang:

1) Pengembang menyarankan kepada guru mata pelajaran untuk memanfaatkan silabus ini dengan sebaik mungkin dalam proses pembelajaran.

2) Dalam mengimplementasikan silabus, guru diharapkan dapat menerapkan semua komponen silabus dalam pembelajaran, agar dapat tercipta pembelajaran yang mengembangkan keterampilan abad 21.

3) Dalam mengembangkan RPP, guru sebaiknya menjadikan silabus ini sebagai acuan pengembangan dengan mengikuti prosedur pengembangan produk.
4) Silabus ini juga perlu dikembangkan lebih lanjut sesuai dengan karakteristik daerah, agar terdapat nilai-nilai daerah yang terkandung dalam proses pembelajaran.

\section{UCAPAN TERIMA KASIH}

Puji syukur kepada Allah SWT atas rahmat, hidayah dan karunia-Nya sehingga saya dapat menyelesaikan Tugas Akhir Skripsi ini. Saya ucapkan terimakasih kepada seluruh pihak yang terlibat dalam penelitian dan penulisan skripsi ini, sehingga penelitian ini dapat berjalan dengan lancar.

\section{DAFTAR PUSTAKA}

Alismail, H. A., \& McGuire, P. (2015). 21st Century Standar and Curriculum: Current Research and Practice. Journal of Educational and Practice.

Allen, M., \& Sites, R. (2012). Leaving ADDIE for SAM: An Agile Model for Developing the Best Learning Experience. United States America: ASTD Press.

Bell, D. V. (2016). Twenty-first Century Education: Transformative Education for Sustainability and Responsible Citizenship. Journal of Teacher Education For Sustainability.

Branch, R. M. (2009). Instructional Design: The ADDIE Approach. New York: Springer.

BSNP. (2010). Paradigma Pembelajaran Nasional Abad XII.

C.M, R., C.V, B., \& M.D, M. (1978). What is The Design Science of Instruction? Journal of Instructional Development.

Daryanto, \& Karim, S. (2017 ). Pembelajaran Abad 21. Yogyakarta: Gava Media.

Endah, L., \& Amri, S. (2013). Panduan Memahami Kurikulum 2013. Jakarta: Prestasi Pustaka. 
Hidayat, S. (2013). Pengembangan Kurikulum Baru. Bandung: PT Remaja Rosdakarya.

Katadata. (2018, 12 5). 2018, Jumlah penduduk Indonesia mencapai 265 juta jiwa. Retrieved from Katadata.co.id: https://databoks.katadata.co.id/datapu blish/2018/05/18/2018jumlahpenduduk-indonesia-mencapai265juta-jiwa

Kebudayaan, M. P. (2018). Lampiran Peraturan Menteri Pendidikan dan Kebudayaan Nomor 34 Tahun 2018. Jakarta: Kementerian Pendidikan dan Kebudayaan.

Mulyasa. (2013). Pengembangan dan Implementasi Kurikulum 2013. Bandung: PT. Remaja Rosdakarya.

Murti, K. E. (2015). Pendidikan Abad 21 dan Implemnetasinya pada Pembelajaran di sekolah Menengah Kejuruan untuk Paket Keahlian Desain Interior. Artikel Kurikulum 2013.

Narwanti, S. (2012). Panduan Menyusun Silabus dan Rencana Pelaksanaan Pembelajaran (Konsep, Implementasi, dan Penelitian). Yogyakarta: Familia (Group Relasi Inti Media).

P21. (2018). P21 Framework Definitions. united States: P21 Partnership for 21st Century Learning.

SMK, T. P. (2018). Peningkatan Proses Pembelajaran dan Penilaian Pembelajaran Abad 21 dalam Meningkatkan Kualitas Pembelajaran SMK. Jakarta: Direktorat Pembinaan Sekolah Menengah Kejuruan.

Suparman, A. (2004). Desain Instruksional. Jakarta: Universitas Terbuka.

Suprayekti, \& Agustyarini. (2015). Analisis Peserta Dididk dalam Teknologi Pendidikan. Jakarta: Lembaga Pengembangan Pendidikan UNJ.

Technopedia. (2018, 12 5). Artificial Intelligence (AI). Retrieved from
Technopedia:

https://www.techopedia.com/definitio n/190/artificial-intelligence-ai

Wisnubro. (2018, 12 1). Jangan khawatir masih banyak profesi baru di era industri 4.0. Retrieved from JPP: https://jpp.go.id/ekonomi/industri/319 783-jangan-khawatir-masihbanyakprofesi-baru-di-era-industri-4-0 